This is the peer-reviewed version of the article:

Perić, A. (2020). Public engagement under authoritarian entrepreneurialism: the Belgrade Waterfront project. Urban Research \& Practice, 13:2, 213-227, DOI:

10.1080/17535069.2019.1670469

To link to this article: https://doi.org/10.1080/17535069.2019.1670469

Full Terms \& Conditions of access and use can be found at https://www.tandfonline.com/action/journalInformation?journalCode=rurp20 All rights reserved.

(C) 2019 Informa UK Limited, trading as Taylor \& Francis Group 


\title{
Public engagement under authoritarian entrepreneurialism: the Belgrade Waterfront project
}

\author{
Ana Perić \\ - Lecturer and Senior Researcher \\ Institute for Spatial and Landscape Development, \\ Swiss Federal Institute of Technology, ETH Zurich, Zurich, Switzerland \\ aperic@ethz.ch \\ - Research Fellow \\ Faculty of Architecture, University of Belgrade, Belgrade, Serbia
}

\begin{abstract}
Urban megaprojects as a spatial manifestation of neoliberalism are in transitional societies considered a tool for extra-profit for private developers and a source of great corruption among the high-level public authorities. Consequently, such a relationship has negative effects on socio-spatial reality. The paper illustrates how a large-scale unitary project - the Belgrade Waterfront project - jeopardizes the public participation through: the misuse of legal procedures and spatial planning instruments, neglect of private property rights, and simulation of public debate. The conditions enabling democratic social, political and professional environment as a backbone for citizen involvement in public issues are briefly indicated in conclusion.
\end{abstract}

Keywords:

Urban development, megaprojects, citizen participation, nation-state politics, Serbia, Belgrade Waterfront 


\section{Introduction: urban megaprojects in post-socialist cities}

Limited role of planners, neoliberal transition, shift to the western model of democratic decision-making, orientation of the legislation towards legitimization of illegal developments, all set the course for a dynamic socio-spatial restructuring in the states on the "periphery of capitalism' (Stanilov, 2007; Tasan-Kok, 2004; Tsenkova \& Nedović-Budić, 2006; Hirt, 2005; Doytchinov, Djukić \& Ioniţă, 2015). Accompanied by the expansion of global economy, urban megaprojects find fertile ground for developing spatial patterns of post-socialist cities (Zeković, Maričić \& Vujošević, 2018; Cope, 2015; Cook, 2010). However, led by the demand for extra-profit to their developers, megaprojects in the context of wild neoliberalism clearly indicate social distortion - instead of being controller to the market-led development, state authorities become the partners to foreign investors; spatial planners lack strength to resist such partnership letting the public interest to be drown in the whirlpool of private sector needs; finally, missing the support from both state and experts, citizenry tries to cope with authoritarian entrepreneurialism pursuing its own, mostly informal mechanisms. The following lines briefly illustrate some of the most remarkable examples of a large-scale urban (re)development emphasizing mostly the superior position of private sector, opportunism among the governmental structures, lack of professional expertise and, finally, neglect of public interest.

The project EURO 2012 in Warsaw elucidates the complex dynamics between the state government and major corporations resulting in political cronyism instead of the state responsible for providing the framework for market competition. Such a monopoly manipulation leaves little space for other actors to enter the arena of socio-spatial transformation (Cope, 2015). On the other hand, the regeneration of Karlin district in Prague, shows the asymmetric set of power relations between foreign investors and municipal authorities in favor of private sector. This appeared due to the lack of local engagement - both local businesses, but also general public - that encouraged low levels of participation in the decision-making (Cook, 2010). In contrast to this, the redevelopment of the dilapidated site Corvin in Budapest is an example of a win-win situation not only for district authorities and private developers, but also for local population, which was proactive, organized, supported by local administration and, hence, successful in convincing the investors into the benefit of preserving local identity and social values at the expense of additional housing area (Keresztély \& Scott, 2012). However, the examples of public interest violation by powerful parties, be this 
state or developers, are more numerous. The project Zagreb on Water is a manifestation of neoliberal urban development, hence raising the questions about flexible governance approaches, ownership structures and regulations, and social inclusion (Djurasovic, 2016). Another Croatian example of the public space usurpation is the transformation of the green area on the hill Srdj into golf resort serving only private interests, rather than the public interest of the citizens of Dubrovnik. Public reaction against such a development was organized in a form of local referendum to influence local and national policies. However, as Zdunić (2017) points out, a sequence of events that followed the referendum indicated that Croatian political system is closed in terms of allowing social movements to influence spatial policies. In sum, while these are all different cases, the issue of citizen participation in decision-making processes is present across all of them.

To elucidate the previously mentioned obstacles in socio-spatial reality of post-socialist cities, I present the distinctive example of the Belgrade Waterfront (BW) project, emphasizing the role of civil sector in protecting the public goods and public interest. In methodological terms, I conduct in-depth qualitative case study: 1) I screen the laws, plans, strategies, regulations, and contracts to describe critical relationships between the private developers' incentives and the public sector's responses to them, 2) using the discourse analysis of the media announcements provided by the civil sector organizations between 2012 and 2017, I identify the main narrative among citizenry and their critical remarks to the steps taken in both preparation and implementation of the project, and 3) using the content analysis of scholarly articles on the current urban development in Serbia, I critically assess the professional position towards citizen engagement in public issues with considerable spatial impact. In conclusion, the steps towards substantial citizen involvement are provided given that they follow the democratic development of Serbia.

\section{Neoliberal challenges facing urban development in Belgrade}

In late 2000, Serbia created a democratically elected government for the first time after more than half a century. This designated the start of a pluralist political culture and a redecentralization of power. For example, the Act on Self-governance (OG RS 9/2002) provided local authorities with the legal and decision-making power in budgeting and spatial planning within its administrative boundaries. Nevertheless, the absence of appropriate measures, institutional capacity, and political reforms when embracing a market-driven economy 
constitutes 'a messy and uneven process' (Cope, 2015). Hence, even today - almost twenty years after the change of the authoritarian political regime, Serbia is considered a 'protodemocracy' (Vujošević, 2010). Consequently, spatial planning instruments are ineffective and citizen involvement is low (Maričić, Cvetinović \& Bolay, 2018).

Three crucial laws clearly illustrate the weak position of participatory spatial planning in the transitional social and political context of Serbia. These were easily implemented as they relied on the mutually dependent relationship between politicians and private investors, on the one hand, and neglected civil society on the other, inherited from the 1990s. The planning law from 2003 (OG RS 47/2003) cancelled the expert debate and even abolished the possibility of informing the public about the beginning of the procedure of public insight, therefore only the debate among the members of the plan approval commission remained (Čolić, 2009). In 2004, the Act on Privatization (OG RS 45/2005) made it possible for private consortia to buy the state (social) enterprises. Thus, private bodies became the owners of the building, but still not the land on which it was situated. However, the conversion of land into private property in 2009, according to the new Act on Planning and Construction (OG RS 72/2009), converted use-right into the ownership-right.1 Under such manipulative conditions, the civil initiatives appeared in the form of grassroots movements that took over the role of the public interest advocate (Grubbauer \& Čamprag, 2018). Although the public opinion finds the legal support in the modified planning law (OG RS 145/2014) - 'early public insight' allows citizens to express their opinion on certain urban issues in an early phase of plan making - the participation of civil sector in planning is still weak. The lack of knowledge among the planning professionals on how to implement new participatory mechanisms, as well as their disinterest, mistrust and fear to communicate with citizens (Maričić, Cvetinović \& Bolay, 2018), makes the citizen engagement still rather unstructured and spontaneous: public voices are not heard enough, citizens are mainly passive recipients of information, and civil sector is usually omitted from the urban decision-making process (Perić \& Maruna, 2012; Maruna \& Čolić, 2017).

\footnotetext{
1 In sum, the developers who bought the objects automatically became the owners of the land too, without having to pay any recompense for it. Moreover, the plots bought by the private sector were situated in the most exclusive areas of Belgrade - river waterfronts, central city areas, historical sites, etc. It was clear that investors were not willing to continue with the previous land use (city port, industrial complex), but rather invest in more profitable uses such as residential and office complexes. Briefly put: transition, along with all the practical problems described above, created a completely 'distorted image' on how to treat private interests and how to recognize investors and developers as legitimate stakeholders in the planning process (Perić \& Maruna, 2012).
} 
Professional planning rooted in the comprehensive planning model has no respect for the open market demands in the spatial development domain (Vujošević \& Nedović-Budić, 2006), and there is still a neglect of the collaborative planning, despite its introduction through informal strategic planning engaging large (foreign) funds (Lazarević Bajec, 2009). According to the comprehensive planning model, the planners' activities are directed towards achieving public interest in a close cooperation with the governing structures. Nevertheless, in a transitional society moving towards the market-based economic system, planners are left unable to understand the complexity of the altered socio-economic framework (Maruna, 2015). They lack knowledge of the humanities, reckoning instead only on purely technical disciplines and engineering skills. Observed from the planning practice perspective, modern planners need to accept that they do not have the monopolistic position in plan-making, strongly ingrained in their narrow professional expertise, anymore. On the contrary, they must be aware that other stakeholders (be these from the private or civil sector) also have legitimate interests (Peric \& Maruna, 2012). The close cooperation between the governmental bodies and the private sector still flourishes in the spatial planning domain - in the first years after the democratic elections the politicians built the strong relationships with the domestic tycoons, while the current regime is close to foreign investors (Perić \& Miljuš, 2017). Nevertheless, all the principles of fuzzy collaboration stay the same: satisfying only partial interest leads to deformed spatial development (Lazarević Bajec, 2009).

\section{Belgrade Waterfront project: neglecting urban democracy}

Before elucidating the current controversies around the BW project, a brief history of the site development in shown (Kovačević, 2014; Perić, 2016; Perić \& Hoch, 2017). The idea to create the new urban center of Belgrade on the right bank of the Sava River, at the bottom of the socalled Sava Amphitheater, was embedded in the first master plan of Belgrade of 1923. As it was recognized as a site of regional and even national importance in all the following Belgrade master plans, its potential was explored through a number of studies and urban design competitions organized during the 1970s and 1980s, in the golden era of Yugoslav urban planning and design. The most famous are: the Home of Friendship (1975) (Fig. 1), prepared by the team of urban planners and designers led by Miloš Perović, and the Town on Water (Varoš na vodi) (1990) (Fig. 2), by the Urban Planning Institute of Belgrade, important for they included both banks of the Sava River in order to reset Belgrade's urban history and place some public buildings (opera, museums), which Belgrade still lacks today. Even during the 1990s in 
time of great political crisis, economic sanctions and poverty, the project Europolis (1995) was developed for the area of the Sava Amphitheater, as a capital project of the authoritarian political regime. In the next twenty years, the area continued to deteriorate, and, thus, became one of the largest brownfield areas in the Belgrade central zone covered by old railway tracks and dilapidated housing. The BW project was for the first time announced as the flagship project during the 2012 political campaign of the then largest opposition party, which won the elections with a great majority of voices. The cornerstone for its future development was set in September 2015, designating a grand political project financed by Eagle Hills, the United Arab Emirates (UAE) investor, with considerable subsidies provided by Serbian government.2

The controversial BW project, covering almost 90-ha area close to the confluence of two rivers and the historical core of the city of Belgrade (Fig. 3), is currently seen as paradigmatic in the public and real estate domains in Serbia. For the political structures, it is the 'best practice' example of urban development. But professionals claim it as a drastic usurpation of both the formal planning procedures and professional expertise, while citizens have been constantly struggling for more transparency and active involvement in the decision-making process. In sum, the BW project depicts the absence of: 1) accountability in decision-making, 2) monitoring and control systems, and 3) mechanisms for evaluating social, economic, and environmental impacts (Zeković, Maričić \& Vujošević, 2018). These aspects speak clearly for insufficient participation of the general public in a project of 'national importance'.3

Briefly put, the national level politicians (led by ex-prime minister, nowadays (2019) the president of Serbia) made strategic decisions in respect to the BW project, hence, avoiding any kind of a public debate with a range of interested parties. Only the Urban Planning Institute (UPI) of Belgrade, the urban planning office of the City of Belgrade, was involved in the process of plan-making, due its tight relationship with the political regime (Orlović Lovren, Maruna \& Crnčević, 2016; Perić, 2016). Three distinctive irregularities, serving as a base for 
creating the plan of the BW area and its further implementation, illustrate key elements of authoritarian entrepreneurialism and inferior professional position, on the one hand, and the citizens' response towards both the planners and decision-makers on the other.

\subsection{Simulation of public debate}

In the regular spatial planning practice, the project elaboration follows the rules and parameters given in the plan. However, in the case of the BW, the international architectural office (SOM Architects) prepared the preliminary design project (without prior consultation with the professional organizations or with the citizens of Belgrade) to serve as a base for its elaboration into the urban plan by the UPI, as a necessary instrument for the future construction on site (Kovačević, 2014). This plan for the $\mathrm{BW}_{4}$ is in its nature totally different from the rest of the official Master Plan of Belgrade 2021 and, therefore, it was added ex post into it in the form of the amendments (Zeković, Maričić \& Vujošević, 2018).

As an immediate response, the civil sector through its own initiative, 'Don't let Belgrade d(r)own!' (Ne da(vi)mo Beograd!), raised its voice by formulating the objections to the proposed amendments (Čukić, Sekulić, Slavković \& Vilenica, 2015). With a help of another collective, the Ministry of Space (Ministarstvo prostora), the citizens of Belgrade together with young experts discussed changes to the plan and filed over 3,000 complaints to proposed changes. The procedure of public insight that followed gathered over 200 people as well as representatives of the city authorities and professional institutions (Čukić et al., 2015). Although the session lasted for more than six hours, all of the complaints were rejected, or only superficially taken into consideration and the Amendments to the Master Plan of Belgrade (OG CB 70/2014) were verified in September 2014. The citizens received a valuable lesson: existing democratic participatory tools proved to be only a simulation without any real effective power (Čukić \& Perić, 2019).

\subsection{Misuse of legal instruments}


Another irregularity of the plan for the BW area is its legal nature. Namely, the Master Plan of Belgrade, as the highest-tier urban plan, cannot be immediately implemented, but only through regulatory plans. This includes the rounds of public debates and approvals. Considering that such a procedure is extremely time consuming, Serbian politicians adopted a proactive approach - in June 2014, a month before the 'masterplan' for the BW area was prepared, the Government made an official decision on creating the special spatial plan (Kovačević, 2014). Namely, the Plan for the Area of Specific Use is, according to the planning law (OG RS 121/2012), created only 1) for non-urban areas of particular importance (i.e. mining and coal seams, flooding areas, natural resorts, etc.), and 2) in accordance to the higher-tier plans (i.e. regional or national spatial plans). Oddly, none of these conditions were fulfilled in respect to the BW area.

The civil sector, acting again as the safeguard of the public interest in spatial planning decisionmaking, organized public debates among the prominent national experts in various domains (sociology, economy, public administration, spatial planning, etc.), with the final aim of addressing the decision-makers (Fig. 4). However, these gatherings under the title "What is hidden beneath the surface of the 'Belgrade Waterfront", running in October 2014 in parallel with the procedure of creating the spatial plan (Čukić et al., 2015), influenced mainly the public. The ruling political structures stayed 'deaf' to the citizens' calls, thus, demonstrating an elementary ignorance of democratic decision-making (Čukić \& Perić, 2019).

The culmination against the new Plan for the Area of Specific Use happened in November 2014 when the activists of the 'Don't let Belgarde d(r)own' initiative (now officially formed into NGO and much more numerable) opted for a different tactics to interrupt the process of legitimizing the BW project (Public debate, 2014). In addition to the regularly and officially sent complaints on the new spatial plan, in the performance called "Operation lifebelt" the activists used creative energy to ban the plan approval (Fig. 5). Contrary to their expectations, and despite the noise, the interruption did not occur. Instead, the members of the planning commission continued their work, complaints were again rejected, and the session was deemed successful. Once again, this has proven the total impermeability of the stakeholders to any form 
of public debate (Čukić \& Perić, 2019). The spatial plan for the BW (Fig. 6) was adopted in January 2015 (OG RS 7/2015).5

\subsection{Demolition of private property}

The third peculiarity refers to the Lex Specialis - Act on Establishing the Public Interest and Special Procedures of Expropriation and the Issuance of Building Permit for the Project Belgrade Waterfront, proposed for adoption in April 2015.6 In its essence, it is not obvious how the highly commercial BW project can preserve and be in the public interest. If the public interest is even prescribed by law, it is not clear enough how this works in practice as specific regulations on how to implement the mentioned law do not exist (Zeković, Maričić \& Vujošević, 2018).

The activists of the 'Don't let Belgrade d(r)own' warned of the core shortcoming of the law (Fig. 7) - it is not about the choice between the dilapidated private houses, on the one hand, and city growth through the BW project on the other. It is about land expropriation for an exclusively commercial project that fulfills the needs of the private investor only. The public interest and the state itself are sidelined (Lex Specialis, 2015). In spite of the public complaints, the law was adopted (OG RS 34/2015), designating the start of the official construction on the BW area, which happened half a year later.

Finally, a particular detail that clearly depicts the political power demonstrated towards the citizens is the demolition of the private property located within the boundary of the BW project. More precisely, during the night of April 26, 2016, the dilapidated building stock (though still used for living) was totally torn down (Fig. 8). Communal officers were not reachable that

\footnotetext{
5 This specific spatial plan was made by the Republic Agency for Spatial Planning (RASP) in full accordance to the Belgrade Waterfront Concept Masterplan, Eagle Hills, Abu Dhabi. For years, this state-owned agency was responsible for creating spatial plans. However, once the document was made (in a record timeframe, only five months after the decision was issued), the RASP was abolished in December 2014 according to the planning law (OG RS 132/14) and all its tasks were undertaken by the Serbian Ministry of Construction, Transport and Infrastructure. Hence, the plan-making as well as its expert control where united into one governmental body, thus representing direct conflict of interests, centralization of power, and lack of transparency in the process of plan-making for the BW area.

6 This law came into being because, according to the Act confirming the Agreement on Cooperation between the Government of the Republic of Serbia and the Government of United Arab Emirates (OG RS 3/2013), Serbia is obliged to adopt any changes to other laws in a way they are desirable for foreign investor.
} 
night, so the affected citizens felt totally helpless (Whose city?, 2016). Citizens' protests were held regularly in 2016 and 2017 (Fig. 9). The court case is still not solved.

\section{In conclusion: towards effective public engagement}

Wild neoliberalism is still a reality in Serbia, as neoliberal main pillars - market-driven economy and democracy - are still highly contested. While lacking institutional capacity for regulating the implementation of neoliberal economic principles, the privatization of state land and resources fuels the capture of public goods mainly for advantage of foreign private developers. Administrative and political decentralization is only declaratively prescribed, while practice faces the monopoly of one political party solving urban issues at the nation-state level. Against such paradox and with strong ties between national government and private investors, citizen engagement is highly endangered: despite the legislation that guarantees the public involvement in spatial planning-related matters, the instruments to operationalize the citizens' demands do not exist. As a result, public reaction to political decisions turn to be wishful thinking with the constant and immense influence of politics on citizen engagement.

Some lessons drawn from the other post-socialist countries that in the course of their transitional histories also faced the problems of dominant politics in steering urban development are as follows (Grubbauer \& Čamprag, 2018; Cope, 2015; Cook, 2010; (Keresztély \& Scott, 2012):

- Avoid nationalist and populist discourse in promoting urban megaprojects to diminish political patronage and corruption;

- Strengthen institutional capacity (both knowledge and finance) of local authorities to face the top-down decision-making;

- Use innovative planning procedures (formal and informal) to enable participation of a wide variety of stakeholders;

- Enable an effective feedback between the public sector planners and citizenry to create trust, mutual respect, and, finally, cooperation; and

- Reassess regulatory mechanisms to clearly address on which jurisdictional level, with what means, and with what purpose public interest is defined. 
In sum, changes in planning instruments and governance mechanisms towards the implementation of the civil sector practices in spatial policies depend on political, professional, and social will, as well as a readiness to change the decision-making system. Only when Serbia paves the way towards its democratic development, will public input be truly incorporated in the planning process.

\section{Acknowledgements}

The author is thankful to Prof. Mickey Lauria and Prof. Carissa Schively Slotterback for the constructive and inspiring comments on the previous paper version.

\section{Declaration of interests}

No potential conflict of interest was reported by the author.

\section{References}

Cook, A. (2010). The expatriate real estate complex: Creative destruction and the production of luxury in postsocialist Prague. International Journal of Urban and Regional Research, 34(3): 611-628.

Cope, B. (2015). Euro 2012 in Poland: Recalibrations of statehood in Eastern Europe. European Urban and Regional Studies, 22(2): 161-175.

Čolić, R. (2009). Participation in Urban Strategic Planning and Knowledge Development: Example of the Strategic Development Plan of the City of Niš (doctoral dissertation) (in Serbian). Belgrade: Faculty of Architecture, University of Belgrade.

Čukić, I., Sekulić, D., Slavković, Lj. \& Vilenica, A. (2015). Report from Belgrade Waterfront. Eurozine, May 2015. Accessed on June 16, 2018 from www.eurozine.com/report-from-belgrade-waterfront/.

Čukić, I. \& Perić, A. (2019). Transformation of the Spatial Planning Approach in Serbia: Towards Strengthening the Civil Sector? In B. Scholl, A. Perić \& M. Niedermaier (Eds.), Spatial and Transport Infrastructure Development in Europe: Example of the Orient/East-Med Corridor. Hannover: Academy for Spatial Research and Planning (ARL) (forthcoming).

Djurasovic, A. (2016). Rethinking Large-Scale Development Projects in Belgrade and Zagreb. Accessed on January 27, 2019 from http://cas.uniri.hr/tag/zagreb-on-sava/.

Doytchinov, G., Djukić, A. \& Ioniță, C. (Eds.). (2015). Planning Capital Cities: Belgrade, Bucharest, Sofia. Graz: Verlag der Technischen Universität Graz.

Grubbauer, M. \& Čamprag, N. (2018). Urban megaprojects, nation-state politics and regulatory capitalism in Central and Eastern Europe: The Belgrade Waterfront project. Urban Studies, DOI: $10.1177 / 0042098018757663$.

Hirt, S. (2005). Planning the Post-Communist City: Experiences from Sofia. International Planning Studies, 10(34), 219-240.

Keresztély, K. \& Scott, J.W. (2012). Urban Regeneration in the Post-Socialist Context: Budapest and the Search for a Social Dimension. European Planning Studies, 20(7), 1111-1134.

Kovačević, B. (2014). Vučić's Belgrade: Walled City (interview by B. Mihajlović) (in Serbian). Radio Slobodna Evropa, July 13, 2014. Accessed on January 26, 2019 from http://aas.org.rs/bojan-kovacevic-vucicevbeograd-zazidani-grad/.

Lazarević Bajec, N. (2009). Rational or collaborative model of urban planning in Serbia: institutional limitations. Serbian Architectural Journal, 1, 81-106.

Lex Specialis (2015, April 2). Accessed on October 27, 2018 from https://nedavimobeograd.wordpress.com/page/16/ 
Lynch, L. (2016). Opinion: those behind the demolitions in Belgrade's nightlife district must be held to account. The Calvert Journal, July 21. Accessed on July 23, 2019 from https://www.calvertjournal.com/articles/show/6451/savamala-belgrade-demolitions-protests-ne-davimobeograd.

Maričić, T., Cvetinović, M. \& Bolay, J.-C. (2018). Participatory Planning in the Urban Development of PostSocialist Serbia. In J.-C. Bolay, T. Maričić \& S. Zeković (Eds.), A Support to Urban Development Process. Lausanne/Belgrade: CODEV EPFL/IAUS.

Maruna, M. (2015). Can Planning Solutions Be Evaluated without Insight into the Process of their Creation? In M. Schrenk, V. Popovich, P. Zeile, P. Elisei \& C. Beyer (Eds.), Plan Together-Right Now-Overall Proceedings of the REAL CORP 2015 Conference (pp. 121-132). Vienna: REAL CORP.

Maruna, M. \& Čolić, R. (2017). Model for Integrated Urban Disaster Risk Management at the Local Level: Bottom-up Initiatives of Academics. In A. Galderisi \& A. Colucci (Eds.), Smart, Resilient and Transition Cities. Emerging Approaches and Tools for a Climate-Sensitive Urban Development (pp.195-202). Amsterdam: Elsevier.

Orlović Lovren, V., Maruna, M. \& Crnčević, T. (2016). Contributing towards more sustainable cities - learning through collaboration. In W. Leal-Filho \& L. Brandli (Eds.), Engaging Stakeholders in Education for Sustainable Development at University Level (pp. 33-44). London: Springer.

Perić, A. (2016). The evolution of planning thought in Serbia: Can planning be 'resilient' to the transitional challenges? In C. Hein (Ed.), History-Urbanism-Resilience-Proceedings of the 17th International Planning History Society Conference (vol.7, pp. 181-193). Delft: TU Delft Open.

Perić, A. \& Hoch, C. (2017). Spatial planning across European planning systems and social models: A look through the lens of planning cultures of Switzerland, Greece and Serbia. In J. A. Ferreira et al. (Eds.), Spaces of Dialog for Places of Dignity: Fostering the European Dimension of Planning - E-Proceedings of the AESOP 2017 Conference (pp. 1247-1258). Lisbon: University of Lisbon.

Perić, A. \& Maruna, M. (2012). The Representatives of Social Action in Waterfront Regeneration - the Case of the Brownfield Site 'Belgrade Port' (Predstavnici društvene akcije u procesu regeneracije priobalja - slučaj braunfild lokacije 'Luka Beograd'). Sociologija i prostor, 50(1), 61-88.

Perić, A. \& Miljuš, M. (2017). Spatial and urban planning in Serbia: a look through the lens of deliberative approach. Spatium - International Planning Review 37, 49-57.

Public debate. (2014, November 8). Accessed on October 27, 2018 from https://nedavimobeograd.wordpress.com/page/17/

Tasan Kok, T. (2004). Budapest, Istanbul, and Warsaw: Institutional and Spatial Change. Delft: Eburon.

Tsenkova, S. \& Nedović-Budić, Z. (Eds.) (2006). The Urban Mosaic of Post-Socialist Europe. Heidelberg, New York: Psysica-Verlag.

Urban Planning Institute of Belgrade (2018). 70 Years of Urban Planning Institute of Belgrade - Book II: Plans. Belgrade: UPI. Accessed on July 20, 2019 from http://timeline.urbel.com.

Vujošević, M. (2010). Collapse of strategic thinking, research and governance in Serbia and possible role of the spatial plan of the Republic of Serbia (2010) and its renewal. Spatium - International Planning Review 23, 22-29.

Vujošević, M. \& Nedović-Budić, Z. (2006). Planning and societal context - The case of Belgrade, Serbia. In S. Tsenkova \& Z. Nedović-Budić (Eds.), The urban mosaic of post-socialist Europe: space, institutions and policy (pp. 275-294). Heilderberg: Springer.

Whose City? (2016, June 28). Accessed on October 27, 2018 from https://nedavimobeograd.wordpress.com/page/13/

Zdunić, N. (2017). Political Elites and Urban Social Movements in Croatia: Political Opportunities of the Citizens' Initiative Srd is Ours. OZP - Austrian Journal of Political Science, 45(4), 19-28.

Zeković, S., Maričić, T. \& Vujošević, M. (2018). Megaprojects as an Instrument of Urban Planning and Development: Example of Belgrade Waterfront. In S. Hostetter, S. Najih Besson \& J.-C. Bolay (Eds.), Technologies for Development: From Innovation to Social Impact (pp. 153-164). London: Springer.

\section{Legislation}

OG RS 9/2002 (Official Gazette of the Republic of Serbia 9/2002). The Act on Self-governance (Zakon o lokalnoj samoupravi). 
OG RS 45/2005 (Official Gazette of the Republic of Serbia 45/2005). The Act on Privatization (Zakon o privatizaciji).

OG RS 72/2009, 121/2012, 132/2014, 145/2014 (Official Gazette of the Republic of Serbia 72/2009, 121/2012, 132/2014, 145/2014). The Act on Planning and Construction (Zakon o planiranju i izgradnji).

OG RS 3/2013 (Official Gazette of the Republic of Serbia 3/2013). The Act confirming the Agreement on Cooperation between the Government of the Republic of Serbia and the Government of United Arab Emirates (Zakon o potvrđivanju Sporazuma o saradnji između Vlade Republike Srbije i Vlade Ujedinjenih Arapskih Emirata).

OG CB 70/2014 (Official Gazette of the City of Belgrade 70/2104). The Amendments on the Master Plan of Belgrade (Izmene i dopune Generalnog plana Beograda 2021).

OG RS 7/2015 (Official Gazette of the Republic of Serbia 7/2015). The Spatial plan of Belgrade Waterfront (Prostorni plan područja posebne namene uređenja dela priobalja grada Beograda - područje priobalja reke Save za projekat „Beograd na vodi”).

OG RS 34/2015 (Official Gazette of the Republic of Serbia 34/2015). Lex Specialis - The Law on Establishing the Public Interest and Special Procedures of Expropriation and the Issuance of Building Permit for the Project "Belgrade Waterfront" (Zakon o utvrdjivanju javnog interesa i posebnim postupcima eksproprijacije i izdavanja gradjevinske dozvole radi realizacije projekta izgradnje "Beograd na vodi”).

\section{Figure captions}

Fig. 1: The Home of Friendship was conceived as a multifunctional centre connecting the banks of the Sava River in the area of the Sava Amphitheatre. Source: Urban Planning Institute of Belgrade, 2018.

Fig. 2: The Town on Water proposed a wide variety of public spaces, bridges and boulevards, highlighting the urban core that includes the Sava River and its banks. Source: Urban Planning Institute of Belgrade, 2018.

Fig. 3: The model of the Belgrade Waterfront project. Source: www.belgradewaterfront.com

Fig. 4: "What is hidden beneath the surface of the "Belgrade Waterfront" - public debates with renown national experts, October 2014. Source: https://nedavimobeograd.wordpress.com/page/18/

Fig. 5: Performance "Operation lifebelt" during the public debate on the Spatial Plan for BW on November 5, 2014 Source: Kamerades kolektiv, https://nedavimobeograd.wordpress.com/page/17/

Fig. 6: The Spatial Plan for the Belgrade Waterfront area. Source: Urban Planning Institute of Belgrade, 2018.

Fig. 7: Protest by 'Don’t let Belgrade d(r)own' on the adoption of Lex Specialis. May 2, 2015. Source: Miloš Stošić i Kamerades kolektiv, https://nedavimobeograd.wordpress.com/page/17/

Fig. 8: The demolished houses in the Belgrade Waterfront area. Source: Lynch, 2016.

Fig. 9: Protest walk organized by ‘Don’t let Belgrade d(r)own’ on July 18, 2016. Source: Lynch, 2016. 